\title{
Study on the relationship between project management and organizational efficacy in nonprofit organizations
}

\author{
I-Chan Kao ${ }^{\mathrm{a}}$ \\ General Education Center, Open University of Kaohsiung, Taiwan
}

\begin{abstract}
This study treats the members in nonprofit organizations (NPOs) as subjects, and explores the origination, planning, control, and completion of project management in NPOs, as well as the general performance of organizational efficacy, such as environmental satisfaction, organizational atmosphere, operational performance, job engagement, and work quality. It also probes into the relationship and effect. By various research methods, such as literature review and questionnaire survey, this study attempts to determine if project management in NPOs can significantly enhance organizational efficacy. This study finds that different NPOs have significant differences in the general performance of project management and organizational efficacy. When the performance of project management in NPOs is more significant, organizational efficacy is higher. Project management in NPOs has a significant path relationship to organizational efficacy; therefore, reinforcement of vocational training in the project management of NPOs could improve performance, which would have significant effect on enhancing organizational efficacy.
\end{abstract}

\section{Introduction}

\subsection{Research motives}

Nonprofit Organizations (NPO) are organizations or groups that do not aim to make profits[1]. The principal objective is to support or cope with issues or events of concern by individuals or the public; therefore, the related fields are broad, including art, charity, education, politics, public policy, religion, academic, and environmental protection. They also supplement the gap between social demand and governmental supply. As enterprises, the operations of NPO aim to produce profits; however, the difference is that NPOs make profits by the service subjects and service content initiated by the organizations, which tend to be considered as the main characteristic of this type of organization.

However, some experts have argued that the major difference between NPO and enterprises is that NPO are restricted by law or morality, and cannot distribute profits to owners or shareholders. Therefore, they are independent, public, and civil. Nowadays, in society, NPOs are sometimes called "the third sector" and in comparison to the governmental sector (the first sector) and private sector of enterprises (the second sector), they are the third force to influence society. Although NPOs state "nonprofit", they must produce the profits of organizational operations as capital for activities. However, as the revenues and expenditures are limited, they obtain funds through public fund raising

\footnotetext{
${ }^{a}$ Corresponding author : kic0929@ouk.edu.tw
}

(C) The Authors, published by EDP Sciences. This is an open access article distributed under the terms of the Creative Commons Attribution License 4.0 (http://creativecommons.org/licenses/by/4.0/). 
or donations from public and private sectors. In addition, they are often exempt from taxation. Sometimes, private donations to NPOs can be benefited by tax deductions. In addition, charity groups are one kind of NPO and non-governmental organizations can also be called NPOs.

The activities of NPO project management include the following 6 fields[2]: (1) environmental protection, ecology, and resource protection; (2) poverty relief and promotion of economic and social development of developing countries; (3) rights protection for minorities; (4) community services for townships; (5) economic intermediary services, including various types of economic intermediary organizations, such as civil groups and industrial groups consisting of managers, professional lawyer offices, accountants, and auditors; (6) charity and relief. Project management emphasize the limitations of time, cost, quality, and scope, and must consider execution, monitoring risks, human resources, stakeholders, communication, and procurement in order to accomplish their goals. Therefore, in terms of organizational type and the operational items of NPO's, project management is the core of the said management and operations.

Hsu (2000) argued that NPO's play the roles of development and innovation, reform and initiation, value maintenance, service offering, expansion of social participation, etc. However, when implementing projects, NPO encounter the instability of funds, labor, and materials, and lack project management competence. Thus, the performances of NPO role functions can be extremely different. Situ (1999), Hsu (2000), Hsiao (2000), and Chang et al. (2005) stated that the problems encountered by Nonprofit Organizations include incomplete guidance and management of governmental regulations, unstable positions, financial difficulties, overly complicated political background, lack of specific efficacy, and failure to implement institutionalized management. Thus, how do NPO's enhance organizational effectiveness and accomplish their role functions through effective project management performance? This is the motive of this study.

\subsection{Research purposes}

Based on the previous statements of research motives, the research purposes are shown, as follows:

1. To recognize the implications of NPO project management and organizational efficiency.

2. To explore general performance of project management and organizational efficiency of NPO with different backgrounds.

3. To analyze the path relationship between NPO project management competence and organizational effectiveness.

4. According to the research findings, this study proposes suggestions to enhance NPO project management competence performance and organizational effectiveness as reference for NPO's to strengthen their project management competence and organizational effectiveness.

\subsection{Research method}

By literature review, this study collects books, journals, magazines, and papers associated with NPO's project management, and organizational effectiveness, and analyses them to obtain the basic concepts. Secondly, it generalizes the related literature and suggestions of scholars and experts of research and practice on NPOs, project management, and organizational effectiveness, and edits the questionnaire on general NPO project management and organizational efficiency. This study adopts questionnaire survey to investigate the on-the-job adult students of the Open University of Kaohsiung that have participated in NPO activities. Through questionnaire collection and statistical analysis, this study explores the subjects' perceptions of the current performances of NPO project management and organizational efficiency. The questionnaires of this study are completed as both written and online questionnaires.

\section{Implications of NPO project management and organizational efficiency}




\subsection{Implications of NPO project management}

Most NPOs have active, innovative, flexible, and public organizational characteristics, and provide multiple channels for the public to consider and participate in public policies. By the force of groups, they directly or indirectly initiate related value and actions, which they promote to society. They represent the essence of sovereignty for the people, and are a critical factor of progress and stability in a democratic society[3]. Thus, NPOs play the role of service Vanguard or Service Pioneer, Value Guardian, Improver or Advocator, Educational Provider, Service Provider, policy assistant, reminder and counseling, supervision, and balance; such activities enhance social welfare, initiate reform, maintain value, improve a negative system, provide diverse negotiation and communication channels for society, accomplish highly-efficiency objectives through flexible organization, increase exchanges between international societies, train international professional talents, and offer opportunities for international recognition [4-6].

In order to effectively demonstrate organizational functions to accomplish organizational visions and missions, NPOs must execute and cope with human resource management, marketing management, fund raising management, performance management, accountability, social business, etc. [7]. Nevertheless, NPOs encounter difficulties and challenges, such as organizational mission, public persistence, establishment of goals, effective power, organizational legitimacy, finance and resource shortages, cost measurement and control, commercialization and industrialization, stimulation of work teams, service performance evaluation, autonomic governance, multiple demands of service subjects, organizational structure and service expansion, professional research, international development, and sustainable operation [3-11]. Peter. F. Drucker (1990) argued that the priority of the operations of NPOs is to transform donators into contributors; secondly, it proposes objectives for communities and the entire organization, validates missions and positions, leader roles, defines performance, develops marketing strategies, reforms, and funds, reinforces human resources and international relationships (including employees, board of directors, volunteers, and community), and develops self-development opportunities and potential from the perspectives of individuals, executors, and leaders, in order to break through the difficulties and blind spots of NPOs in operation and management.

The operational patterns of NPOs are very similar to the operational processes of project management, and include the following project management characteristics: specific management objectives, extremely complicated and numerous uncertain task factors, cross-departmental or crossfield cooperation for tasks, funds and operational resources based on external donations, and stakeholders include industry, government, academic fields, research, and community, thus, while they are numerous and have complicated demands, they value the social benefit of tasks instead of economic benefit $[2,12]$. According to standards of project management competence (IPMA Competency Baseline, ICB 3.0), as established by the International Project Management Association (IPMA), "project" denotes a certain period of time, an organization's temporary involvement, and efforts to accomplish certain goals [13]; in addition, the Project Management Institute (PMI) states that "project" is unique product, service, or result created by temporary efforts [14].

Based on the definitions of previous international professional organizations (IPMA \& PMI) and project management scholars [15-30] of project management, this study suggests that "NPO project management" means that, with limited resources and fixed and unique visions, NPOs apply effective management methods and systematic management processes to integrate labor and resources to accomplish tasks.

According to the definitions of scholars [14], [30-36], [62] of competence and project management competence, this study argues that "NPO project management competence" means NPO personnel's project management knowledge and explicit competence of skills. Kao (2017) treated project management initiation, planning, execution, control, and closing as the framework for project management competence, and cognitive and skills performance of the five processes of project management as the items of project management competence. Upon attitude and moral regulations of project management, the said researcher regarded the project management executors of industry, government, academic, and research circles in Taiwan as the subjects. By empirical research, it constructed Taiwan's project management competence scale of 80 items, including 30 items of project 
management cognitive competence performance, 30 items of project management technical competence performance, 10 items of project management attitude competence performance, and 10 items of project ethical competence performance.

This study adopts the technical competence performance of project management, as established by Kao (2017), and 5-point Likert scale as the design criteria to construct a scale of general NPO project management, which includes project initiation (5 items), project planning (10 items), project control (10 items), and project closing (5 items). When the scores of items and dimensions are higher, NPO project management performance is more significant. When the scores are lower, NPO project performance is less satisfying. The content is shown, as follows [30]:

\subsubsection{Technical competence performance of project initiation}

01. I will initiate projects with benefits.

02. I will set project goals.

03. I will propose a project concept book (draft).

04. I will operate the tools and techniques used for project feasibility analysis.

05. I will propose a project authorization letter.

\subsubsection{Technical competence performance of project planning}

01. I will propose a project plan.

02. I will operate the tools and techniques used for project schedule planning.

03. I will operate the tools and techniques used for project budget planning.

04. I will operate the tools and techniques used for project quality planning.

05. I will operate the tools and techniques used for project scope planning.

06. I will operate the tools and techniques used for project risk planning.

07. I will operate the tools and techniques used for project human resource planning.

08. I will operate the tools and techniques used for project equipment and materials planning.

09. I will operate the tools and techniques used for project procurement and bid planning.

10. I will operate the tools and techniques used for communication planning with a project's interested parties.

\subsubsection{Technical competence performance of project controlling and management}

01. I will control and manage the project schedule.

02. I will control and manage the project budget.

03. I will control and manage project quality.

04. I will control and manage project scope.

05. I will control and manage project risk.

06. I will control and manage the project's human resources.

07. I will control and manage the project's equipment and materials.

08. I will control and manage the procurement bidding of a program.

09. I will effectively control and manage the interested parties of the project.

10. I will control and manage the related laws and contracts of the project.

\subsubsection{Technical competence performance of project closing}

01. I will operate the tools and techniques of project closing.

02. I will operate the tools and techniques of closing the project's contracts.

03. I will operate the tools and techniques of closing the project's administrative affairs.

04. I will hold project review meetings.

05. I will manage the knowledge and experience documents of the project. 


\subsection{Implication of organizational effectiveness}

While the implications of effectiveness are broad, they can be generally classified into "quality" and "quantity"; however, these two views are not totally different or confronting, but are part of complicated organizations; therefore, they enhance complexity. Profit organizations mostly rely on financial indicators as the criteria of measurement. NPO schools, public sectors, hospitals, and various types of civil groups tend to treat organizational innovative performance, learning and growth, operational processes, the accomplishment of goals, job engagement, organizational climate, and job quality as criteria of measurement. Thus, the two show certain degrees of differences [37-41].

Based on the definitions and views of scholars [37-44] regarding organizational effectiveness, this study defines NPO efficacy, as follows: NPO members of different levels and categories fulfill their duties, accomplish the organizational objectives, and make efforts for the plans set by the organization to result in the positive performance of organizational management and operation. NPO efficacy in this study refers to the following five items:

(1) Environment satisfaction: NPO members' satisfaction with business execution, colleagues' relationship, salary, high-rank supervision, and promotion of the current organization.

(2) Organizational climate: NPO members' perceptions of colleagues' relationships.

(3) Operational performance: NPO members' satisfaction with treatment and outcome of affairs related to the people and things in the organization.

(4) Job engagement: NPO members' involvement in organizational affairs.

(5) Job quality: NPO members' perceptions of the progress of professional competence, mastery of affair treatments, proper application of various resources to enhance job efficiency, presentation of business outcomes, etc.

This study generalizes literature related to organizational effectiveness as the scale of general NPO efficacy and adopts a five-point scale; where content refers to environment satisfaction (6 items), organizational climate (5 items), operational performance (5 items), job engagement (5 items), and job quality (6 items), for a total of 27 items. When the scores of items and dimensions are higher, NPO efficacy is higher. When the scores are lower, NPO efficacy is lower. The content is shown, as follows:

\subsubsection{Environment satisfaction}

01 . I am properly respected in the organization.

02. I am satisfied with the award system in the organization.

03. I am satisfied with the work environment in the organization.

04. I am satisfied with the work assigned by the organization.

05. I am satisfied with colleagues' coping with affairs in the organization.

06. I am satisfied with the welfare in the organization.

\subsubsection{Organizational climate}

01. Colleagues' relationships are harmonious.

02. Colleagues get along joyfully at work.

03. My organization is a vigorous team.

04. Interaction between the cadre and members is positive.

05. When colleagues have different opinions, they can communicate and negotiate with each other.

\subsubsection{Operational performance}

01. Colleagues can make efforts to solve the problems encountered by the organization.

02. Different units of the organization establish concrete duties of work and operations are successful. 
03. Colleagues of units in the organization can punctually accomplish the resolutions of meeting.

04. Work performances of colleagues are acknowledged by authorities and different circles of society.

05. The organization can immediately cope with the problems encountered.

\subsubsection{Job engagement}

01. Colleagues always make efforts to the job.

02. I tend to treat organizational goals as personal work objectives.

03. Colleagues tend to share the opinions of reform in various kinds of meeting in the organization.

04. I usually can experience pleasure at work.

05. I have intention to actively cooperate with all measures in the organization.

\subsubsection{Job quality}

01. Colleagues tend to discuss the problems of work and share their experiences during spare time at work.

02. Colleagues can properly use labor, materials, and financial resources in and out of the organization to enhance job outcome.

03. Colleagues all pay attention to the executive strategy and method design of work tasks.

04. The organization assigns jobs according to colleagues' specialties.

05. The organization frequently holds forums for work experience exchange.

06. The organization frequently holds visits in model units with outstanding performance.

\section{Research framework and steps}

Through the previous literature review and analysis, this study generalizes and edits the first draft of the questionnaire on the general situation of NPO project management and organizational efficiency, and invites NPO workers and university scholars and experts in the field of project management as the experts to examine the expert validity of the questionnaire. Regarding NPO workers, this study invites 1 labor group supervisor, 1 supervisor of the chamber of commerce, and 1 supervisor of the community development association as experts to test the draft of the questionnaire scale of this study; secondly, regarding university professors or scholars in the field of project management, by the assistance of colleagues in the Taiwan Project Management Association, this study invites 1 scholar or expert from National Pingtung University, 1 from National Pingtung University of Science and Technology, 1 from Lunghwa University of Science and Technology, 1 from National Kaohsiung First University, 1 from Aletheia University, 1 from the Republic of China Military Academy, and 1 from the Open University of Kaohsiung, to examine the expert validity of this questionnaire.

This study focuses on the on-the-job adult learners from different counties and cities around Taiwan who have participated NPO affairs in the Open University of Kaohsiung, where the sampling unit is the class, and adopts random sampling as the method of the questionnaire survey to explore their different personal background variables, such as gender, age, educational background, job title, organizational history, organizational scale, educational and training, general performance of project management business of the project initiation, project planning, project control, project closing in the NPO, as well as the general perceptions of the organizational effectiveness of organizational environment satisfaction, organizational climate, operational performance, job engagement, and job quality. It also probes into the effective measures to reinforce the organizational efficacy of NPO project management performance, and the performance differences of the different dimensions of project management and organizational effectiveness, as reference for future improvement of educational training systems and reinforcement of project management labor and organizational effectiveness. 
Operations of the research framework (see Figure 1) are based on statistical analysis, such as t test and one-way ANOVA, to conduct difference comparison analysis of subjects' personal background variables on project management variables and the outcome variables of organizational effectiveness; secondly, by path analysis of Structural Equation Modeling (SEM), it probes into the path relation between subjects' operational variables of project management and the outcome variables of organizational effectiveness; finally, based on the research findings, this study states that NPOs properly apply project management to effectively enhance efficacy in order to accomplish organizational objectives and visions.

The framework of this study is shown, as follows:

\begin{tabular}{|c|c|c|}
\hline $\begin{array}{c}\text { Personal background } \\
\text { variables }\end{array}$ & A & $\begin{array}{c}\text { Project } \\
\text { Management }\end{array}$ \\
\hline \multirow{2}{*}{$\begin{array}{c}\text { Gender } \\
\text { Age } \\
\text { Educational background } \\
\text { Job title } \\
\text { Organizational history } \\
\text { Organizational scale } \\
\text { Educational \& training }\end{array}$} & \multirow{5}{*}{ A } & $\begin{array}{l}\text { Project initiation } \\
\text { Project planning } \\
\text { Project control } \\
\text { Project closing }\end{array}$ \\
\hline & & $\mathrm{B} \uparrow$ \\
\hline & & $\begin{array}{l}\text { Organizational } \\
\text { Effectiveness }\end{array}$ \\
\hline \multirow[t]{2}{*}{$\begin{array}{l}\text { A:t test or One Way AN } \\
\text { B:Path analysis by SEM }\end{array}$} & & $\begin{array}{l}\text { Environment } \\
\text { Satisfaction } \\
\text { Organizational }\end{array}$ \\
\hline & & $\begin{array}{c}\text { Climate } \\
\text { Operational } \\
\text { Performance } \\
\text { Job engagement } \\
\text { Job quality }\end{array}$ \\
\hline
\end{tabular}

Figure 1. Research framework.

The steps of the research process are shown, as follows:

Step 1: Related literature collection and generalization of research variables.

Step 2: Selection of research samples.

Step 3: Editing of the questionnaire.

Step 4: Practice the questionnaire survey.

Step 5: Questionnaire retrieval and statistical analysis.

Step 6: Generation of statistical results and suggestions.

Step 7: Completion and submission of the research findings report.

\section{Research results}

\subsection{Descriptive statistics result}

The descriptive statistical results of the samples are shown in Table 1. Regarding gender, there are 150 males, accounting for $54.0 \%$ of the total subjects, and 128 females, accounting for $46.0 \%$. Regarding age, " $21-40$ years old" is the most, and there are 189 subjects, accounting for $68.0 \%$; second is " $41-60$ years old, there are 79 subjects, accounting for $28.4 \%$; the least is above 61 years old, there are 10 subjects, accounting for 3.6\%. Regarding educational distribution, "Below (including) Senior high 
school and vocational school" is the most, there are 146 subjects, accounting for $52.5 \%$; the second is "college or university", there are 116 subjects, accounting for $41.7 \%$; the least is "graduate school", there are 16 subjects, accounting for $5.8 \%$. Regarding subjects' job title, "Member" is the most, there are 153 subjects, accounting for 55.0\%; the second is "Officer", there are 104 subjects, accounting for $37.4 \%$; the least is "Responsible person", there are 21 subjects, accounting for $7.6 \%$. Regarding subjects' history in the organization, "More than 21 years" is the most, there are 98 subjects, accounting for $35.3 \%$; the second is "2--10 years" and "Less than 1 year", there are 68 and 60 subjects, accounting for $24.5 \%$ and $21.6 \%$, respectively; the least is " $11--20$ years", there are 52 subjects, accounting for $18.7 \%$. Regarding subjects' organizational scale, "Under 50 people" is the most, there are 119 subjects, accounting for 42.8\%; second is "Over 201 people" and "51-100 people", there are 72 and 68 subjects, accounting for $25.9 \%$ and $24.5 \%$, respectively, the least is " $101-200$ people", there are 19 subjects, accounting for $6.8 \%$. Regarding subjects' educational training, 151 subjects never received project management related training courses, accounting for 54.3\%; 127 subjects have received project management related training courses, accounting for $45.7 \%$.

Table 1. Questionnaire survey on general NPO project management and organizational efficiency.

\begin{tabular}{|c|c|c|c|c|}
\hline Variables & Group & $\begin{array}{c}\text { Number } \\
\text { of subjects }\end{array}$ & Percentage & $\begin{array}{l}\text { Cumulative } \\
\text { Percentage }\end{array}$ \\
\hline \multirow{2}{*}{ Gender } & Male & 150 & 54.0 & 54.0 \\
\hline & Female & 128 & 46.0 & 100.0 \\
\hline \multirow{3}{*}{ Age } & 21--40 years old & 189 & 68.0 & 68.0 \\
\hline & 41--60 years old & 79 & 28.4 & 96.4 \\
\hline & Above 61 years old & 10 & 3.6 & 100.0 \\
\hline \multirow{3}{*}{ Educational background } & $\begin{array}{l}\text { Below (including) Senior high school } \\
\text { and vocational school }\end{array}$ & 146 & 52.5 & 52.5 \\
\hline & College or university & 116 & 41.7 & 94.2 \\
\hline & Graduate school & 16 & 5.8 & 100.0 \\
\hline \multirow{3}{*}{ Job title } & Member & 153 & 55.0 & 55.0 \\
\hline & Officer & 104 & 37.4 & 92.4 \\
\hline & Responsible person & 21 & 7.6 & 100.0 \\
\hline \multirow{4}{*}{ Organizational history } & Less than 1 year & 60 & 21.6 & 21.6 \\
\hline & 2--10 years & 68 & 24.5 & 46.0 \\
\hline & 11--20 years & 52 & 18.7 & 64.7 \\
\hline & More than 21 years & 98 & 35.3 & 100.0 \\
\hline \multirow{4}{*}{ Organizational scale } & Under 50 people & 119 & 42.8 & 42.8 \\
\hline & $51-100$ people & 68 & 24.5 & 67.3 \\
\hline & 101-200 people & 19 & 6.8 & 74.1 \\
\hline & Over 201 people & 72 & 25.9 & 100.0 \\
\hline \multirow{2}{*}{ Educational \& training } & $\begin{array}{l}\text { Never received project management } \\
\text { related training courses }\end{array}$ & 151 & 54.3 & 54.3 \\
\hline & $\begin{array}{l}\text { Have received project management } \\
\text { related training courses }\end{array}$ & 127 & 45.7 & 100.0 \\
\hline
\end{tabular}

$\mathrm{N}=278$

\subsection{Confirmatory Factor Analysis result of questionnaire scale}

\subsubsection{Validation of convergent validity}


Thomopson (2004) argued that a measurement model can accurately reflect the dimensions. Thus, before SEM analysis, measurement model analysis must be conducted. According to the two-stage model analysis of Kline (2005), this study examines the SEM model for model fit. When it is acceptable, it subsequently evaluates the total SEM model [45]. According to the suggestions of Hair, Anderson, Tatham, and Black (2009) and Fornell and Larcker (1981), the CFA measurement standard is shown, as follows: (1) factor loading is higher than .50; (2) composite reliability is higher than .60; (3) average variance extracted is higher than .50. CFA analytical results of this study show that the factor loading of dimensions is .0.76 .98; composite reliability is .94 .99, and average variance extracted is .75 .88 (see Table 2), which shows that dimensions of this study reveal convergent validity.

Table 2. Summary of the data for convergence validity verification.

\begin{tabular}{|c|c|c|c|c|c|c|c|c|c|}
\hline \multicolumn{6}{|c|}{ Parameter estimates of model } & \multicolumn{4}{|c|}{ Convergent validity } \\
\hline $\begin{array}{c}\text { Latent } \\
\text { variables }\end{array}$ & $\begin{array}{l}\text { Manifest } \\
\text { variables }\end{array}$ & $\begin{array}{c}\text { Non- } \\
\text { standardized } \\
\text { factor } \\
\text { loading }\end{array}$ & $\begin{array}{c}\text { Standard } \\
\text { error } \\
\text { S.E. }\end{array}$ & $\begin{array}{c}\mathrm{t}- \\
\text { value }\end{array}$ & $\mathrm{P}$ & $\begin{array}{l}\text { Standardized } \\
\text { factor } \\
\text { loading }\end{array}$ & SMC & C.R & $\begin{array}{c}\mathrm{AV} \\
\mathrm{E}\end{array}$ \\
\hline \multirow{5}{*}{$\begin{array}{l}\text { Project } \\
\text { initiation }\end{array}$} & $\mathrm{Aa} 01$ & 1 & & & & 0.88 & 0.77 & \multirow{5}{*}{0.96} & \multirow{5}{*}{0.81} \\
\hline & $\mathrm{Aa} 02$ & 1.02 & 0.05 & 22.65 & $* * *$ & 0.91 & 0.83 & & \\
\hline & $\mathrm{Aa} 03$ & 1.07 & 0.05 & 22.49 & $* * *$ & 0.91 & 0.82 & & \\
\hline & $\mathrm{Aa} 04$ & 1.07 & 0.05 & 23.09 & $* * *$ & 0.92 & 0.85 & & \\
\hline & $\mathrm{Aa} 05$ & 1.1 & 0.05 & 21.11 & $* * *$ & 0.88 & 0.78 & & \\
\hline \multirow{10}{*}{$\begin{array}{l}\text { Project } \\
\text { planning }\end{array}$} & $\mathrm{Ab} 01$ & 1 & & & & 0.85 & 0.73 & \multirow{10}{*}{0.98} & \multirow{10}{*}{0.83} \\
\hline & $\mathrm{Ab} 02$ & 1.12 & 0.05 & 23.32 & $* * *$ & 0.94 & 0.89 & & \\
\hline & $\mathrm{Ab} 03$ & 1.15 & 0.05 & 23.54 & $* * *$ & 0.95 & 0.90 & & \\
\hline & $\mathrm{Ab} 04$ & 1.12 & 0.05 & 23.88 & $* * *$ & 0.95 & 0.91 & & \\
\hline & $\mathrm{Ab} 05$ & 1.11 & 0.05 & 23.25 & $* * *$ & 0.94 & 0.89 & & \\
\hline & $\mathrm{Ab} 06$ & 1.06 & 0.05 & 21.71 & $* * *$ & 0.91 & 0.83 & & \\
\hline & $\mathrm{Ab} 07$ & 1.08 & 0.05 & 22.02 & $* * *$ & 0.92 & 0.84 & & \\
\hline & $\mathrm{Ab} 08$ & 1.04 & 0.05 & 21.50 & $* * *$ & 0.91 & 0.82 & & \\
\hline & Ab09 & 1.07 & 0.05 & 19.93 & $* * *$ & 0.87 & 0.76 & & \\
\hline & $\mathrm{Ab} 10$ & 0.96 & 0.05 & 19.08 & $* * *$ & 0.85 & 0.73 & & \\
\hline \multirow{10}{*}{ Project control } & $\mathrm{Ac} 01$ & 1 & & & & 0.96 & 0.93 & \multirow{10}{*}{0.99} & \multirow{10}{*}{0.88} \\
\hline & $\mathrm{Ac02}$ & 1.00 & 0.02 & 45.49 & $* * *$ & 0.98 & 0.95 & & \\
\hline & $\mathrm{Ac03}$ & 0.95 & 0.03 & 38.42 & $* * *$ & 0.95 & 0.90 & & \\
\hline & Ac04 & 0.98 & 0.02 & 41.33 & $* * *$ & 0.96 & 0.93 & & \\
\hline & Ac05 & 1.00 & 0.03 & 39.97 & $* * *$ & 0.96 & 0.92 & & \\
\hline & Ac06 & 1.00 & 0.03 & 36.66 & $* * *$ & 0.94 & 0.89 & & \\
\hline & Ac07 & 1.00 & 0.03 & 36.31 & $* * *$ & 0.94 & 0.89 & & \\
\hline & Ac08 & 0.82 & 0.04 & 21.41 & $* * *$ & 0.81 & 0.66 & & \\
\hline & Ac09 & 0.97 & 0.03 & 33.84 & $* * *$ & 0.93 & 0.86 & & \\
\hline & Ac10 & 1.05 & 0.03 & 32.56 & $* * *$ & 0.92 & 0.85 & & \\
\hline \multirow{4}{*}{ Project closing } & Ad01 & 1 & & & & 0.94 & 0.88 & \multirow{4}{*}{0.96} & \multirow{4}{*}{0.83} \\
\hline & Ad02 & 1.00 & 0.03 & 33.56 & $* * *$ & 0.96 & 0.91 & & \\
\hline & Ad03 & 0.99 & 0.03 & 32.86 & $* * *$ & 0.95 & 0.90 & & \\
\hline & $\mathrm{Ad} 04$ & 0.88 & 0.04 & 20.93 & $* * *$ & 0.82 & 0.68 & & \\
\hline
\end{tabular}




\begin{tabular}{|c|c|c|c|c|c|c|c|c|c|}
\hline \multicolumn{6}{|c|}{ Parameter estimates of model } & \multicolumn{4}{|c|}{ Convergent validity } \\
\hline $\begin{array}{c}\text { Latent } \\
\text { variables }\end{array}$ & $\begin{array}{l}\text { Manifest } \\
\text { variables }\end{array}$ & $\begin{array}{c}\text { Non- } \\
\text { standardized } \\
\text { factor } \\
\text { loading }\end{array}$ & $\begin{array}{l}\text { Standard } \\
\text { error } \\
\text { S.E. }\end{array}$ & $\begin{array}{c}\mathrm{t}- \\
\text { value }\end{array}$ & $\mathrm{P}$ & $\begin{array}{l}\text { Standardized } \\
\text { factor } \\
\text { loading }\end{array}$ & SMC & C.R & $\begin{array}{c}\mathrm{AV} \\
\mathrm{E}\end{array}$ \\
\hline & Ad05 & 0.88 & 0.04 & 24.69 & $* * *$ & 0.88 & 0.77 & & \\
\hline \multirow{6}{*}{$\begin{array}{l}\text { Organizational } \\
\text { environment } \\
\text { satisfaction }\end{array}$} & $\mathrm{Ba} 01$ & 1 & & & & 0.79 & 0.63 & \multirow{6}{*}{0.96} & \multirow{6}{*}{0.78} \\
\hline & $\mathrm{Ba} 02$ & 1.22 & 0.07 & 17.46 & $* * *$ & 0.89 & 0.79 & & \\
\hline & $\mathrm{Ba} 03$ & 1.24 & 0.07 & 17.63 & $* * *$ & 0.89 & 0.80 & & \\
\hline & $\mathrm{Ba} 04$ & 1.28 & 0.07 & 18.17 & $* * *$ & 0.91 & 0.83 & & \\
\hline & $\mathrm{Ba} 05$ & 1.26 & 0.07 & 18.56 & $* * *$ & 0.93 & 0.86 & & \\
\hline & $\mathrm{Ba} 06$ & 1.24 & 0.07 & 17.51 & $* * *$ & 0.89 & 0.79 & & \\
\hline \multirow{5}{*}{$\begin{array}{l}\text { Organizational } \\
\text { colleagues' } \\
\text { interpersonal } \\
\text { relationships }\end{array}$} & $\mathrm{Bb} 01$ & 1 & & & & 0.91 & 0.82 & \multirow{5}{*}{0.95} & \multirow{5}{*}{0.80} \\
\hline & $\mathrm{Bb} 02$ & 1.03 & 0.04 & 27.06 & $* * *$ & 0.94 & 0.89 & & \\
\hline & $\mathrm{Bb} 03$ & 1.07 & 0.04 & 24.38 & $* * *$ & 0.91 & 0.82 & & \\
\hline & $\mathrm{Bb} 04$ & 1.05 & 0.04 & 24.25 & $* * *$ & 0.91 & 0.82 & & \\
\hline & $\mathrm{Bb} 05$ & 0.96 & 0.05 & 18.78 & $* * *$ & 0.81 & 0.66 & & \\
\hline \multirow{5}{*}{$\begin{array}{l}\text { Organizational } \\
\text { administration } \\
\text { and } \\
\text { management } \\
\text { performance }\end{array}$} & $\mathrm{Bc} 01$ & 1 & & & & 0.86 & 0.73 & \multirow{5}{*}{0.96} & \multirow{5}{*}{0.83} \\
\hline & $\mathrm{Bc} 02$ & 1.06 & 0.05 & 21.90 & $* * *$ & 0.92 & 0.85 & & \\
\hline & $\mathrm{Bc} 03$ & 1.07 & 0.05 & 22.14 & $* * *$ & 0.93 & 0.86 & & \\
\hline & $\mathrm{Bc} 04$ & 1.07 & 0.05 & 21.92 & $* * *$ & 0.92 & 0.85 & & \\
\hline & $\mathrm{Bc} 05$ & 1.04 & 0.05 & 21.62 & $* * *$ & 0.92 & 0.84 & & \\
\hline \multirow{5}{*}{$\begin{array}{l}\text { Organizational } \\
\text { colleagues' job } \\
\text { engagement }\end{array}$} & $\mathrm{Bd} 01$ & 1 & & & & 0.85 & 0.72 & \multirow{5}{*}{0.94} & \multirow{5}{*}{0.75} \\
\hline & $\mathrm{Bd} 02$ & 0.98 & 0.05 & 20.13 & $* * *$ & 0.90 & 0.81 & & \\
\hline & $\mathrm{Bd} 03$ & 0.93 & 0.05 & 18.30 & $* * *$ & 0.85 & 0.73 & & \\
\hline & $\mathrm{Bd} 04$ & 1.00 & 0.05 & 19.30 & $* * *$ & 0.88 & 0.77 & & \\
\hline & $\mathrm{Bd} 05$ & 0.88 & 0.05 & 17.96 & $* * *$ & 0.85 & 0.71 & & \\
\hline \multirow{6}{*}{$\begin{array}{c}\text { Organizational } \\
\text { colleagues' job } \\
\text { quality }\end{array}$} & $\mathrm{Be} 01$ & 1 & & & & 0.91 & 0.83 & \multirow{6}{*}{0.95} & \multirow{6}{*}{0.77} \\
\hline & $\mathrm{Be} 02$ & 1.09 & 0.04 & 27.59 & $* * *$ & 0.94 & 0.88 & & \\
\hline & $\mathrm{Be} 03$ & 1.05 & 0.04 & 25.34 & $* * *$ & 0.91 & 0.83 & & \\
\hline & $\mathrm{Be} 04$ & 1.03 & 0.05 & 21.68 & $* * *$ & 0.86 & 0.77 & & \\
\hline & $\mathrm{Be} 05$ & 1.07 & 0.05 & 22.85 & $* * *$ & 0.88 & 0.77 & & \\
\hline & $\mathrm{Be} 06$ & 0.86 & 0.05 & 16.79 & $* * *$ & 0.76 & 0.58 & & \\
\hline
\end{tabular}

$* * * \mathrm{P}<.001$

\subsubsection{Validation of discriminant validity}

Table 3. Bootstrap correlation coefficient $95 \%$ confidence interval.

\begin{tabular}{|cc|c|c|c|c|c|}
\hline \multicolumn{2}{|c|}{ Parameters } & \multirow{2}{*}{ Estimates } & \multicolumn{2}{c|}{ Bias-corrected } & \multicolumn{2}{c|}{ Percentile method } \\
\cline { 4 - 7 } & & $\begin{array}{c}\text { Lower } \\
\text { Bound }\end{array}$ & $\begin{array}{c}\text { Upper } \\
\text { Bound }\end{array}$ & $\begin{array}{c}\text { Lower } \\
\text { Bound }\end{array}$ & $\begin{array}{c}\text { Upper } \\
\text { Bound }\end{array}$ \\
\hline $\begin{array}{c}\text { A0 Project } \\
\text { management }\end{array}$ & $<->\quad \begin{array}{c}\text { B0 Organizational } \\
\text { efficacy }\end{array}$ & 0.27 & 0.20 & 0.35 & 0.20 & 0.34 \\
\hline
\end{tabular}

AMOS provides two types of estimations for the confidence interval: one is the Bias-corrected Percentile Method and the other is the Percentile Method [46]. This study applies the bootstrap confidence interval to test the discriminant validity of the dimensions. With a $95 \%$ confidence level, it 
repeats 1000 times of estimations. According to the calculation results, when the correlation coefficient of the dimensions is lower than 1 with a $95 \%$ confidence interval, it means there is discrimin ant validity among the dimensions [46-48]. The estimated results of this study are shown in Table 3. The confidence intervals of the dimensions are lower than 1 , thus, there is discriminant validity between the two dimensions.

\subsubsection{Verification of goodness-of-fit}

In this study, fit measures are based on the suggestions of Wu (2007), Hsu (2010), Bagozzi and Yi (1988), and Hair et al. (1998). It adopts $\chi 2$ to test ratio of $\chi 2$ and freedom. GFI, AGFI, Root Mean Square Error of Approximation (RMSEA), Comparative Fit Index (CFI), Incremental Fit Index (IFI), Non-Normed Fit Index (NNFI), and NFI are the fit measures of the total model. When SEM samples are more than 200 , the chi-square value $(\chi 2=(n-1) F \min )$ can be too large; in other words, when samples are oversize, the chi-square value can be too large, and the $\mathrm{P}$ value tends to be rejected [46, 49], thus, Bollen and Stine (1992) proposed model revision by Bootstrap. After adjustment, as the chisquare value becomes lower, all fit measures should be recalculated. Regarding calculation results are shown in Table 4; all model fit measures match the standard.

Table 4. Model goodness-of-fit indices.

\begin{tabular}{|c|c|c|c|}
\hline Goodness-of-fit Indexes & \multicolumn{2}{|c|}{ Standard Value } & Model Goodness-of-fit \\
\hline$\chi^{2}$ & The less the better & 2824.99 & Passed \\
\hline$\chi^{2} / \mathrm{df}$ & $<3$ & 1.85 & Passed \\
\hline GFI & $>.9$ & 0.89 & Accepted \\
\hline AGFI & $>.9$ & 0.88 & Accepted \\
\hline RMSEA & $<.08$ & 0.06 & Passed \\
\hline TLI (NNFI) & $>.9$ & 0.95 & Passed \\
\hline CFI & $>.9$ & 0.95 & Passed \\
\hline NFI & $>.9$ & 0.89 & Accepted \\
\hline
\end{tabular}

\subsection{Difference analysis of the variables of personal background variables and NPO project management and organizational efficiency}

Independent sample $t$ testing aims to calculate the mean of two independent samples, and generalizes it to the mean of the original two population, in order to determine if there is significant difference [50]. This study adopts independent sample $t$ testing to conduct difference analysis of different genders and educational training on the variables of the correlation model of NPO project management and organizational efficiency. One-way ANOVA aims to determine if the means of the manifest variables show significant difference upon the effect of different levels[50]. When the test result shows that the $\mathrm{F}$ value is significant, the means shows significant difference between at least one group. Therefore, "multiple Post Hoc" analysis should be applied to further verify the difference [51].

\subsubsection{Difference analysis of gender on variables of correlation model of NPO project management and organizational efficiency}

Regarding the difference comparative analysis of subjects' genders on the dimensions, according to the result of independent sample $\mathrm{t}$ testing, different genders on project control $(\mathrm{t}=-.09, \mathrm{p}=.93)$, organizational administration and management performance $(\mathrm{t}=-1.87, \mathrm{p}=.06)$ do not show significant difference of means; means of project initiation $\left(\mathrm{t}=-3.74^{*}, \mathrm{p}=.00\right)$, project planning $\left(\mathrm{t}=-4.39^{*}, \mathrm{p}=.00\right)$, project closing $(\mathrm{t}=-4.52 *, \mathrm{p}=.00)$, organizational environment satisfaction $(\mathrm{t}=-2.89 *, \mathrm{p}=.00)$, organizational colleagues' interpersonal relationship $\left(\mathrm{t}=-2.50^{*}, \mathrm{p}=.01\right)$ organizational colleagues' job 
engagement $(\mathrm{t}=-2.72 *, \mathrm{p}=.01)$, and organizational colleagues' job quality $(\mathrm{t}=-3.23 *, \mathrm{p}=.00)$ show significant differences. Females are more significant than males.

\subsubsection{Difference analysis of the variables of the correlation model of Education and Training on NPO project management and organizational efficiency}

Regarding the difference analysis of subjects' educational training on the dimensions, according to the result of independent sample $t$ testing, the means of different educational training on project control $(\mathrm{t}=1.21, \mathrm{p}=.23)$ do not show significant difference; the means of project initiation $\left(\mathrm{t}=-7.10^{*}, \mathrm{p}=.00\right)$, project planning $\left(\mathrm{t}=-6.54^{*}, \mathrm{p}=.00\right)$, project closing $\left(\mathrm{t}=-6.66^{*}, \mathrm{p}=.00\right)$, organizational environment satisfaction $\left(\mathrm{t}=-3.97^{*}, \mathrm{p}=.00\right)$, organizational colleagues' interpersonal relationship $\left(\mathrm{t}=-4.57^{*}, \mathrm{p}=.00\right)$, organizational administration and management performance $(\mathrm{t}=-4.46, \mathrm{p}=.00)$, organizational colleagues' job engagement $\left(\mathrm{t}=-4.96^{*}, \mathrm{p}=.00\right)$, and organizational colleagues' job quality $\left(\mathrm{t}=-4.18^{*}\right.$, $\mathrm{p}=.00$ ) show significant differences. Moreover, subjects who have received project management related training courses are more significant than those who never received project management related training courses.

\subsubsection{Difference analysis of age on the variables of the correlation model of NPO project management and organizational efficiency}

Regarding the difference analysis of subjects' ages on the dimensions of project management and organizational effectiveness, according to the result of one-way ANOVA, the means of different ages on project initiation $(\mathrm{F}=1.99, \mathrm{p}=.14)$, project planning $(\mathrm{F}=.90, \mathrm{p}=.41)$, project control $(\mathrm{F}=1.90, \mathrm{p}=.15)$, project closing $(\mathrm{F}=1.10, \mathrm{p}=.34)$, organizational environment satisfaction $(\mathrm{F}=2.13, \mathrm{p}=.12)$, organizational colleagues' interpersonal relationship $(\mathrm{F}=1.23, \mathrm{p}=.30)$, organizational administration and management performance $(\mathrm{F}=.96, \mathrm{p}=.38)$, organizational colleagues' job engagement $(\mathrm{F}=2.15$, $\mathrm{p}=.12)$, and organizational colleagues' job quality $(\mathrm{F}=.39, \mathrm{p}=.68)$ do not show significant difference. In other words, different ages on the variables of the correlation model of NPO project management and organizational efficiency do not show significant difference.

\subsubsection{One-way ANOVA of educational background on the variables of project management and organizational effectiveness}

Regarding the difference analysis of subjects' educational background on the dimensions of project management and organizational effectiveness, according to the result of one-way ANOVA, the means of different educational background on project initiation $(\mathrm{F}=2.59, \mathrm{p}=.08)$, project control $(\mathrm{F}=1.16$, $\mathrm{p}=.32)$ and project closing $(\mathrm{F}=2.65, \mathrm{p}=.07)$ do not show significant difference; the mean of project planning $\left(\mathrm{F}=3.11^{*}, \mathrm{p}=.05\right)$ reveal significant difference. After Scheffe Post Hoc Testing, "Graduate school" is more significant than "College or university"; the mean of organizational colleagues' job engagement $\left(\mathrm{F}=9.07^{*}, \mathrm{p}=.00\right)$ reveal significant difference. After Scheffe Post Hoc Testing, "Graduate school" and "Below (including) Senior high school and vocational school" are higher than "College or university". "Graduate school" and "senior high school and vocational school (including)" do not reveal significant difference; the means of organizational environment satisfaction $\left(\mathrm{F}=6.53^{*}, \mathrm{p}=.00\right)$, organizational colleagues' interpersonal relationship $\left(\mathrm{F}=10.89^{*}, \mathrm{p}=.00\right)$, organizational administration and management performance $\left(\mathrm{F}=7.69^{*}, \mathrm{p}=.00\right)$, and organizational colleagues' job quality $\left(\mathrm{F}=7.56^{*}\right.$, $\mathrm{p}=.00$ ) show significant difference. After Scheffe Post Hoc Testing, "Graduate school" is higher than "Below (including) Senior high school and vocational school" and "College or university". "Graduate school" and "Below (including) Senior high school and vocational school" do not show significant difference. 


\section{organizational effectiveness}

Regarding the difference analysis of subjects' job titles on the dimensions of project management and organizational effectiveness, according to the result of one-way ANOVA, the means of different job titles on project initiation $\left(\mathrm{F}=4.30^{*}, \mathrm{p}=.01\right)$ and organizational environment satisfaction $\left(\mathrm{F}=3.43^{*}\right.$, $\mathrm{p}=.03$ ) show significant difference. After Scheffe Post Hoc Testing, "Member" is higher than "Responsible person"; the means of different job titles on project planning $(\mathrm{F}=2.80, \mathrm{p}=.06)$, project control $(\mathrm{F}=.29, \mathrm{p}=.75)$, project closing $(\mathrm{F}=2.17, \mathrm{p}=.12)$, organizational colleagues' interpersonal relationship $(\mathrm{F}=1.24, \mathrm{p}=.29)$, organizational administration and management performance $(\mathrm{F}=1.77$, $\mathrm{p}=.17)$, organizational colleagues' job engagement $(\mathrm{F}=1.33, \mathrm{p}=.27)$, and organizational colleagues' job quality $(\mathrm{F}=.86, \mathrm{p}=.43)$ do not show significant difference. In other words, different job titles on the variables of the correlation model of NPO project management and organizational efficiency do not show significant difference.

\subsubsection{One-way ANOVA of organizational history on the variables of project management and organizational effectiveness}

Regarding the difference analysis of subjects' organizational history on the dimensions of project management and organizational effectiveness, according to the result of one-way ANOVA, the means of different organizational history on organizational colleagues' job quality $\left(\mathrm{F}=3.63^{*}, \mathrm{p}=.01\right)$ show significant difference. After Scheffe Post Hoc Testing, "2--10 years" is higher than "Less than 1 year"; the means of different organizational history on project initiation $(\mathrm{F}=.83, \mathrm{p}=.48)$, project planning $(\mathrm{F}=1.94, \mathrm{p}=.12)$, project control $(\mathrm{F}=.75, \mathrm{p}=.52)$, project closing $(\mathrm{F}=1.15, \mathrm{p}=.33)$, organizational environment satisfaction $(\mathrm{F}=.61, \mathrm{p}=.61)$, organizational colleagues' interpersonal relationship $(\mathrm{F}=.81$, $\mathrm{p}=.49)$, organizational administration and management performance $(\mathrm{F}=.50, \mathrm{p}=.69)$, and organizational colleagues' job engagement $(\mathrm{F}=.18, \mathrm{p}=.91)$ do not show significant difference. In other words, different organizational history on the variables of the correlation model of NPO project management and organizational efficiency does not reveal significant difference.

\subsubsection{One-way ANOVA of organizational scale on the variables of project management and organizational effectiveness}

Regarding the difference analysis of subjects' organizational scale on the dimensions of project management and organizational effectiveness, according to the one-way ANOVA result, the means of different organizational scales on project initiation $(\mathrm{F}=1.06, \mathrm{p}=.37)$, project planning $(\mathrm{F}=1.64, \mathrm{p}=.18)$, project control $(\mathrm{F}=2.29, \mathrm{p}=.08)$, project closing $(\mathrm{F}=1.52, \mathrm{p}=.21)$, organizational environment satisfaction $(\mathrm{F}=1.13, \mathrm{p}=.37)$, organizational colleagues' interpersonal relationship $(\mathrm{F}=.65, \mathrm{p}=.59)$, organizational administration and management performance $(\mathrm{F}=.31, \mathrm{p}=.82)$, organizational colleagues' job engagement $(\mathrm{F}=.24, \mathrm{p}=.87)$, and organizational colleagues' job quality $(\mathrm{F}=3.33, \mathrm{p}=.80)$ do not show significant difference. In other words, different organizational scales on the variables of the correlation model of NPO project management and organizational efficiency do not reveal significant difference.

\subsection{Path analysis of NPO project management and organizational efficiency}

Table 5. Path analysis of the relation between NPO project management and organizational efficiency.

\begin{tabular}{|ccc|c|c|c|}
\hline \multicolumn{3}{|c|}{ Path relation } & Path value & C.R. & $p$ \\
\hline $\begin{array}{c}\text { Organizational } \\
\text { efficacy }\end{array}$ & $<\rightarrow$ & $\begin{array}{c}\text { Project } \\
\text { management }\end{array}$ & .58 & $10.56^{*}$ & $* * *$ \\
\hline
\end{tabular}

$* \mathrm{P}<.05 * * * \mathrm{P}<.001$ 
The path coefficient of NPO project management and organizational efficiency is 0.58 , which is significant. The results are shown in Table 5.

\subsection{Statistical model and path relation between NPO project management and organizational efficiency}

This study integrates the stratified factors of NPO project management, project initiation, project planning, project control and project closing, and stratified factors of environment satisfaction, organizational climate, operational performance, job engagement, and job quality of NPO efficacy for Confirmatory Factor Analysis of Structural Equation Modeling and path relation analysis. The analytical results are shown in Figure 2.

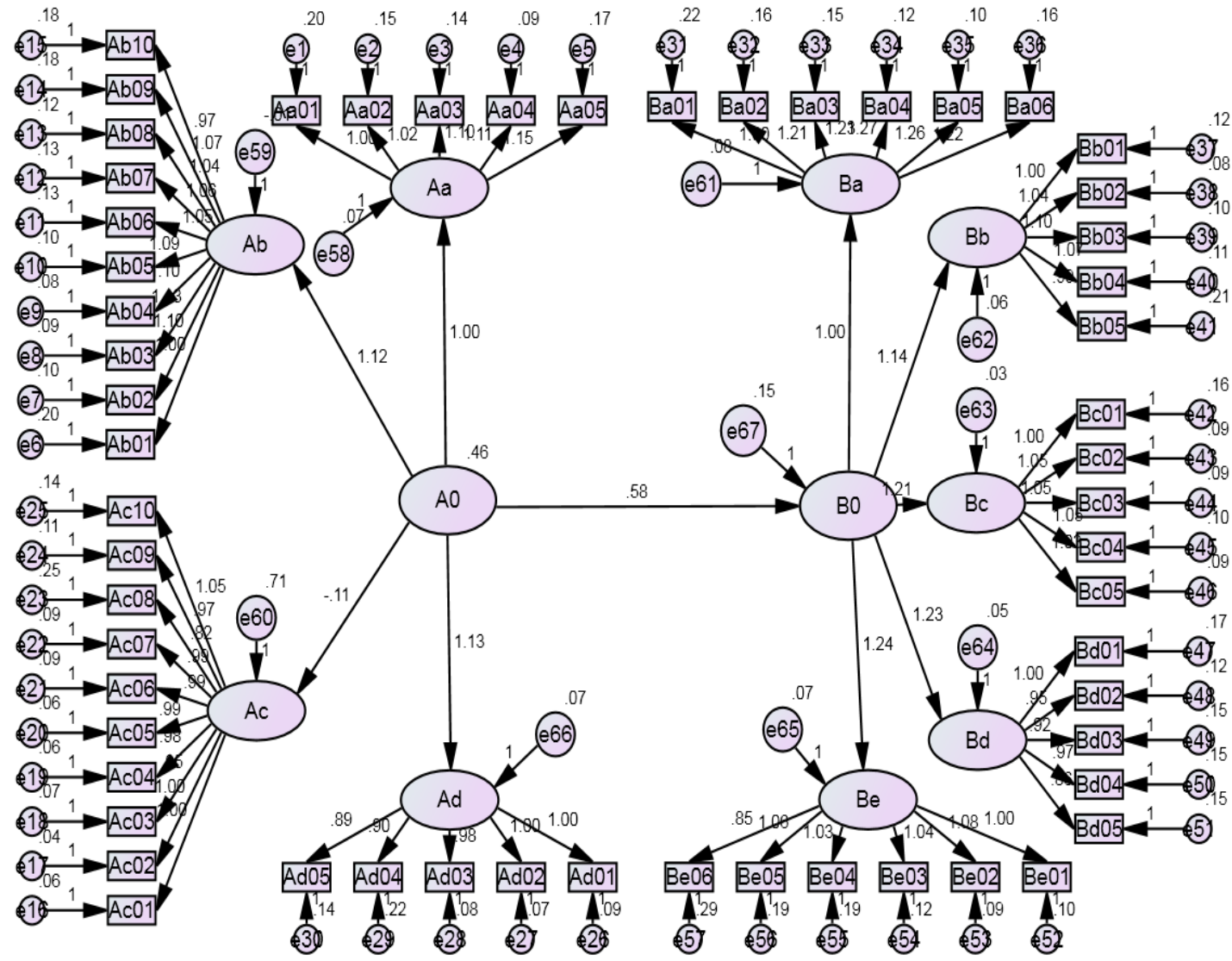

Figure 2. Statistical model and path relation between NPO project management and organizational efficiency.

\section{Conclusion and suggestions}

Based on the research findings, this study generalizes the following conclusions. First, regarding NPO members' cognitive differences of personal background variables, NPO female members' project management performance and organizational effectiveness perception are superior to male members. NPO members who have received project management training are superior to those who never received project management training in terms of project management performance and organizational effectiveness perception; NPO members graduated from graduate school are superior to those graduated from university, college, senior high school, or vocational school in terms of project management performance and organizational effectiveness perception; subjects in NPO with the job 
title of "Member" are superior to those with the job title of "Responsible person" in terms of project initiation performance and perception of satisfaction with organizational environment; NPOs with organizational history within 10 years is superior to that founded within 1 year in terms of perception of organizational job quality. Secondly, there is a path relation between NPO project management and organizational effectiveness.

Based on previous conclusions, this study proposes suggestions for NPO operations and management, as follows. First, it should actively plan project management competence training for NPO male members in order to reinforce the executive outcome of project management and strengthen NPO operational efficacy. NPOs should introduce project management competence training as the occupational training course for organizational members' professional advanced study. It should encourage NPO members to actively study courses in graduate school programs, in order to enhance their professional knowledge, particularly the advanced study of professional degrees in project management and organizational effectiveness, in order to enhance the performance of NPO project management and organizational efficiency; NPO owners should actively participate in project management competence training in order to fulfill organizational missions and positions, vision construction, strategic planning, goal setting, program design, process improvement, value creation, performance reinforcement, and sustainable operation, and lead members to demonstrate NPO functions, such as development and innovation, reform and promotion, value maintenance, service offering, and expansion of social participation; newly founded NPOs should enhance organizational members' project management competence, mastery to cope with affairs, proper use of various resources to increase job efficiency, and active and effective holding of the presentations of business outcomes, in order to upgrade the efficacy of job quality. Secondly, NPOs should actively reinforce organizational members' project management competence, such as project initiation, planning, control, and closing to strengthen the organizational effectiveness of environment satisfaction, organizational climate, operational performance, job engagement, and job quality, in order to effectively accomplish organizational missions and visions.

\section{References}

1. R.D. Anthony and D.W. Young, Management control in Nonprofit organization (Irwin Series in Graduate Accounting, Irwin, 1993)

2. L.L. Chin, Journal of Beijing Technology and Business University (version of social science), 20(6), 63-67(2005)

3. P.H. Kao, NPO operational strategy and management (Hwa Li Publishing, Taiwan, 2012)

4. P.S. Yu(trans), Peter.F. Drucker, Operation of nonprofit organizations (bookzone, Taiwan, 1994)

5. D.H. Situ, Operation and management of nonprofit organizations (bookzone, Taiwan, 1999)

6. T.Y. Chang, T\&D Fashion, 36, 6-24 (2005)

7. S.H. Lin, NPO management (additional version) (Sanmin, Taiwan, 2015)

8. M.H. Chiang, NPO management (Taipei, Taiwan, 2002)

9. C.T. Chiu(ed), Nonprofit department study: governance, departmental interaction and social innovation (Bestwise, Taiwan, 2007)

10. H.H. Hsiao, Y.Y. Kuan and W.P. Lu(ed), Nonprofit department: organization and operation (3rd ed.) (Blueocean, Taiwan, 2000)

11. H.H. Hsiao(ed), Nonprofit department: organization and operation (Blueocean, Taiwan, 2000)

12. M. Wang(ed), Introduction of NPO management (Beijing, China, 2002)

13. Taiwan Project Management Association, Selection of Cases of Management Quality Certification of International Items and C Class Interview (Beijing, China, 2012)

14. PMI, A Guide to the Project Management Body of Knowledge (5th ed.) (Pennsylvania, USA, 2012)

15. H. Kerzner, Project Management: A System Approach to Planning, Scheduling, and Controlling (9th ed.) (New York, USA, 2006)

16. J. Lewis, Fundamentals of Project Management (2nd ed.) (New York, USA, 2002) 
17. J. Lewis, Mastering Project Management (New York, USA, 2007)

18. C.C. Wei, General project management knowledge system (Taipei, Taiwan, 2013)

19. M.J. Kuan, Teaching materials of APMP project manager training (Taoyuan, Taiwan, 2009)

20. K.M. Lu, Project management of software (Taipei, Taiwan, 2009)

21. H.Y. Hsu, P.L. Hsiung, Y.F. Chu, Y.H. Chang, M. Fan, C.M. Huang, H.D. Chou and Z.P. Lu, Basic knowledge and application practice of project management (5th ed.) (New Taipei, Taiwan, 2014)

22. H.H. Lin, M.C. Huangand and W.L. Wang, Project management of software (2nd ed.) (Taipei, Taiwan, 2005)

23. W.D.Yu, Project Management in Practice (Taipei, Taiwan, 2015)

24. W.W. Chuang, 11 lessons to learn project management (revision) (Taipei, Taiwan, 2014)

25. I.C. Kao, Civic knowledge management: feasible strategy to construct project knowledge management system of school education. Published in Y.M. Wu, T.C. Tsai, ed.: Civic Urbanology (18-35) (Kaohsiung, Taiwan, 2009)

26. I.C. Kao, Storage Management Solutions, 1, 154-173 (2013)

27. I.C. Kao, Storage Management Solutions, 1, January, 198-229 (2013)

28. I.C. Kao, Storage Management Solutions, 2, 42-65 (2014)

29. Taiwan Project Management Association, International project management knowledge system (Kaohsiung, Taiwan, 2014)

30. I.C. Kao, MATEC Web of Conferences, 119, 01037 (2017)

31. ICB: IPMA Competence Baseline, IPMA, http://ipma.ch/resources/ipma-publications/ ipmacompetence-baseline (2009)

32. S.C. Chen, P.C. Lin and Y.C. Chen, Psychological Testing, 56(3), 397-430 (2009)

33. D.C. McClelland, American Psychologist, 28(1), 1-24 (1973)

34. L.M. Spencer and S.M. Spencer, Competence at work: Models for superior performance (New York, USA, 1993)

35. C.L. Kang, Employment and training, 15(6), 3-9 (1997)

36. S.C. Wu, Psychological Testing, 60(2), 397-428(2013)

37. W.K. Hoy and C.G. Miskel, Educational administration: Theory, research, and practice, 9th edition (New York, USA, 2013)

38. K.F. Huang, An Interdisciplinary Journal, 64, 51-78(2013)

39. M.D. iPaola and W.K. Hoy, Improving Instruction Through Supervision, Evaluation, and Professional Development (Charlotte, USA, 2014)

40. C.S. Wu, Research on school effectiveness (Psychological Publishing, Taipei, 1992)

41. I.C. Kao, Research on relationship between school teachers' organizational operation strategy and school effectiveness (Taipei, Taiwan, 2003)

42. C.S. Chang, The Effects of Transformational and Transactional Leadership of Elementary School Principals on the Culture Characteristics and Effectiveness of School Organization (Kaohsiung, Taiwan, 2001)

43. M.C. Chin, C.F. Wu and C. Hien, Education and Psychological Study, 37(1), 1-35 (2014)

44. H.Y. Kuo and L.Wu, Journal of Cheng-Shiu University, 19, 279-300 (2006)

45. S.Y. Chen, M.C. Hsu and F. E. Li, Journal of Leisure and Recreation Industry Management, 5(3), 1-21 (2012).

46. W.H. Chang, Techniques of thesis writing (Tingmao, Taipei, 2011)

47. M.C. Hsu, F.C. Pan and C.M. Huang, Journal of Taiwan Society for Sport Management, 11(2), 85-107 (2011)

48. G. Torkzadeh, X. Koufteros and K. Pflughoeft, Structural Equation Modeling, 10(2), 263-275 (2003)

49. M.C. Hsu and H.P. Yen, International Journal of LISREL, 6(1), 24-56 (2013)

50. K.Y. Chen and C.H. Wang, Thesis statistical analysis practice SPSS and operation of AMOS (Wu Nan Books, Taipei, 2011)

51. M.L. Wu and C.T. Tu, SPSS and statistical application analysis (Wu Nan Books, Taipei, 2005) 
52. P.F. Drucker, Managing the Non-profit Organization: Principles and Practice (New York, USA, 1990)

53. M.L. Wu, Structural Equation Modeling: AMOS operation and application (Wu Nan Books, Taipei, 2007)

54. M.C. Hsu, Journal of Sport and Recreation Management, 7(1), 174-18 (2010)

55. C.Fornell and D.F. Larcker, Journal of Marketing Research, 18, 39-50 (1981)

56. J.F. Jr.Hair, R.E. Anderson, R.L. Tatham and W.C. Black, Multivariate data analysis (7th ed.) (Prentice Hall, New Jersey, 2009)

57. R.B Kline, Principles and practice of structural equation modeling (2nd ed.) (Guilford Press, New York, 2005)

58. B. Thomopson, Exploratory and confirmatory factor analysis: Understanding concepts and applications (American Psychological Association, Washington DC, 2004)

59. R.P. Bagozzi and Y. Yi, Journal of the Academy of Marketing Science, 16, 74-94(1988)

60. J.F.Jr. Hair, R.E. Anderson, R.L. Tatham and W.C. Black, Multivariate data analysis (5th ed.) (Prentice Hall, New Jersey, 1998)

61. S.Y. Hsu, Nonprofit organizations and public administration. Published in M.H. Chiang (ed): The third sector: operational strategy and social participation (Taipei, Taiwan, 2000)

62. H.L. Cheng, Research on competence construction of nonprofit organization project management personnel(master's thesis), Graduate Institute of Management, Ming Chuan University (to be published) 